\title{
AN ACTION ON THE EQUITIES: \\ RE-CHARACTERIZING BHASIN AS EQUITABLE ESTOPPEL
}

\author{
KRISH MAHARAJ
}

\begin{abstract}
In its 2014 decision of Bhasin v. Hrynew, the Supreme Court of Canada recognized that a duty of honest performance exists between contracting parties. Academics, practitioners, and courts across the nation have since contemplated the meaning and role of such a duty. This article looks to Australia's doctrine of "equitable estoppel," the equivalent of Canada's "promissory estoppel," to explain the outcome of the Supreme Court's decision. It thereby posits that the duty of honest performance can be re-characterized and interpreted as equitable estoppel. In that manner, the article provides a perspective that clarifies the newly proclaimed duty, and potentially answers several of the outstanding questions regarding the Supreme Court's conclusions in Bhasin.
\end{abstract}

\section{TABLE OF CONTENTS}

I. INTRODUCTION

II. A DOCTRINE AFFECTING CONTRACTS, BUT Not A CONTRACT DOCTRINE . . . . . . . . . . . . . . . . . . 200

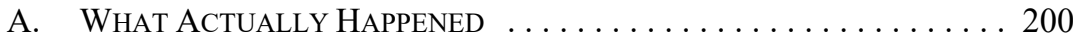

B. Why DHP IS NOT A CLAim In CONTRACT . . . . . . . . . . . . 202

III. Why DHP IS IN ESSENCE EQUitABLE ESTOPPEL . . . . . . . . . . . . . . . 206

A. Why AND How Estoppel Is Relevant At All . . . . . . . . . . 206

B. HOW BHASIN CAN BE VIEWED

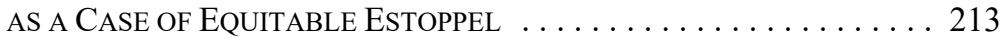

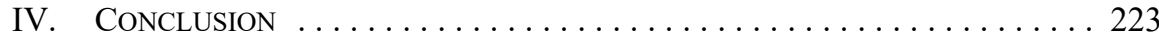

\section{INTRODUCTION}

The Supreme Court of Canada's decision in Bhasin v. Hrynew ${ }^{1}$ addresses a number of questions regarding the role of good faith and commonly held notions of honesty and fair dealing in contract law. The result, however, unfortunately raises more questions than it answers. This article considers this problem and answers two of these questions in particular, namely, what is the newly minted "duty of honest performance" (DHP) in contract, and what does it (or should it) do? This article will answer these questions by re-characterizing DHP as "equitable estoppel," the Australian equivalent of the Canadian doctrine of "promissory estoppel," and proposing the adoption of that approach. The Australian and Canadian doctrines differ in a number of important respects that will require some elaboration. The distinctions of chief concern that will receive the most attention are the availability of the Australian doctrine as a cause of action, the Australian doctrine's ability to respond to

Barrister and Solicitor, Doctoral Candidate, Peter A. Allard School of Law, University of British Columbia. The author is grateful to Professors Bruce MacDougall and Peter Devonshire, and to his colleague Lachlan Caunt, for their thoughtful comments and assistance with this article. Any remaining errors and omissions are those of the author. 
"communications" other than just "promises," and the Australian approach to remedy, which is more flexible than that applied in Canada. ${ }^{2}$

By examining these differences and explaining how equitable estoppel can provide a clearer and less discordant explanation for the outcome in Bhasin than DHP, this article will answer the two aforementioned questions. Further, in so doing it will also answer a number of other outstanding questions related to remedial consequences and the limits of liability. These are questions that the Supreme Court's decision has addressed inadequately at best.

\section{A Doctrine Affecting Contracts, BUT Not a CONTRACT DOCTRINE}

The thesis of this article comes in two parts. The first is that the Supreme Court's description of DHP as contractual in nature is clearly at odds with its impact in the actual case, and accordingly, that it cannot be explained as a doctrine in contract. The second part (found in Part III, below) will explain that in light of the failure of the Supreme Court's explanation, the best explanation available to bridge the gulf between facts and outcome in Bhasin (and cases like it) is equitable estoppel. Subject to modifications, this is the approach that ought to be adopted. To make the first part of my argument, I will argue that there is a disjuncture between the Supreme Court's rhetoric and the outcome of the case. This disconnect demonstrates that equity can provide a better explanation than common law contract doctrine with respect to the operation, and most importantly, the limits, of any doctrine intended to address dishonesty in contractual relations.

\section{A. What Actually Happened}

In order to make the theoretical discussion of Bhasin intelligible for all readers, a summary of the facts and outcome is needed. The parties to the Bhasin case included the plaintiff, Harish Bhasin (carrying on business as Bhasin \& Associates), and the defendants, Larry Hrynew and Heritage Education Funds Inc., formerly known as Canadian American Financial Corp. (Can-Am). Can-Am's business was the marketing of education savings plans through retail dealers, known as enrolment directors, such as Bhasin. ${ }^{3}$ Enrolment directors working under Can-Am were effectively small business owners, not unlike franchisees. ${ }^{4}$ Unfortunately for Bhasin, enrolment directors were not franchisees for the purposes of Alberta law, either under their contract with Can-Am, or otherwise. ${ }^{5}$ An enrolment director's agreement entered into on 5 November 1998 governed the relationship between Bhasin and Can-Am. ${ }^{6}$ The agreement was for an initial term of three years, with automatic renewal unless either party gave written notice of termination at least six months prior to the renewal

2 Although it is still sometimes referred to as "promissory estoppel," the term "equitable estoppel" will be used to denote the Australian doctrine from this point forward, and the term "promissory estoppel" to identify the Canadian doctrine. See Commonwealth of Australia v Verwayen, [1990] HCA 39, 170 CLR 394 at 409-11, Mason CJ [Verwayen].

Bhasin, supra note 1 at para 3.

Ibid at paras 3-5.

Ibid at para 4.

Bhasin v Hrynew, 2011 ABQB 637, [2012] 9 WWR 728 at para 50 [Bhasin QB], rev'd 2013 ABCA 98, 362 DLR (4th) 18 [Bhasin CA], aff'd on other grounds Bhasin, ibid; Bhasin, ibid at para 4 (note that the agreement replaced an earlier agreement of indefinite duration entered into in 1989). 
date. ${ }^{7}$ Such a termination notice was given to Bhasin by Can-Am on 3 May 2001, six months prior to the expiry of the agreement (in other words, effectively at the last possible moment). ${ }^{8}$ Although termination on notice was expressly permitted by the parties' agreement, the circumstances surrounding the termination, and particularly Can-Am's behaviour leading up to it, motivated Bhasin to allege that the termination was wrongful and to bring suit.

The crux of the dispute between Bhasin and Can-Am related to the way in which Can-Am represented certain matters relating to another enrolment director, and large competitor of Bhasin, Hrynew. Hrynew's agency enjoyed a very strong market position as the largest agency of its kind in Alberta, as well as a very positive relationship with the Alberta Securities Commission, the regulator that oversaw the operations of firms like Can-Am. ${ }^{9}$ Prior to Can-Am's notice of termination, Hrynew used his position to pressure Can-Am into compelling a merger between his firm and Bhasin's. ${ }^{10}$ Bhasin for his part had consistently indicated to both Can-Am and Hrynew that he was unwilling to merge his agency with Hrynew's. ${ }^{11}$ The refusal aside, Bhasin understood that Can-Am might attempt to force the issue of a merger, and in August 2000 asked Can-Am whether a merger would be required. ${ }^{12}$ To quote from the Supreme Court decision, Can-Am responded "equivocally" to Bhasin's enquiry, and no indication was given that Can-Am and Hrynew had decided that such a takeover of Bhasin's business would take place. ${ }^{13}$ As a result, the termination notice came as a surprise to Bhasin when it was finally delivered. The result of this unexpected termination was a rather sharp change of fortunes for Bhasin. Left facing the impending loss of the ability to continue marketing and selling the products his business was built on, and with little time to adjust to the new reality, Bhasin wound up losing the entire value of his business. ${ }^{14}$ Most of his employees elected to leave Bhasin's agency and to join Hrynew's, which effectively resulted in the takeover that Hrynew had sought. ${ }^{15}$

Bhasin pursued his claim against Can-Am in the Alberta Court of Queen's Bench on the basis that Can-Am had violated an implied duty of good faith. ${ }^{16}$ Bhasin succeeded at trial on this basis only to have that decision reversed on appeal, owing to an apparent absence of any basis for implying such a term into the parties' agreement. ${ }^{17}$ The enrolment director agreement, and the parties' relationship, was not of the type that had previously been thought to attract such a duty, and it precluded the implication of such a term because of conflict with the contract's express terms, including an entire agreement clause. ${ }^{18}$ The matter reached the Supreme Court of Canada, where the Alberta Court of Appeal's decision was reversed, and where Bhasin ultimately succeeded against Can-Am, albeit for reasons that would not have been expected at the outset. ${ }^{19}$

Bhasin, ibid at para 6 .

Bhasin QB, supra note 6 at paras 206-10.

Bhasin, supra note 1 at para 8.

Ibid at paras 7-9; Bhasin QB, supra note 6 at para 252.

Bhasin QB, ibid at paras 251-52.

Bhasin, supra note 1 at para 12.

Ibid; Bhasin QB, supra note 6 at paras 249-52.

Bhasin, ibid at para 13; Bhasin QB, ibid at paras 258-59.

Bhasin, ibid; Bhasin QB, ibid at para 259.

Bhasin QB, ibid at para 9.

Bhasin CA, supra note 6 at paras 28-35.

Bhasin CA, ibid.

See Bhasin, supra note 1. 
As noted above, Bhasin's claim against Can-Am had been framed as a claim for the violation of an implied duty of good faith. This, however, was most definitely not the basis upon which the Supreme Court found for Bhasin. Instead, the Supreme Court found that CanAm had violated its "duty of honest performance," which was somewhat surprising given that such a duty had not previously been recognized in Canadian law. ${ }^{20}$ It was, or is, a completely new development in Canadian private law, and one that has left many wondering as to its meaning because the Supreme Court did not explain the new duty in any detail. What we do have to shed light on the meaning of the new doctrine, however, is its application in Bhasin itself.

According to the Supreme Court, Can-Am violated its duty of honest performance when it misled Bhasin as to its intentions regarding a merger between Bhasin's agency and Hrynew's, and regarding the potential renewal of Bhasin's contract. ${ }^{21}$ This is despite the fact that Can-Am did not owe Bhasin a duty of disclosure, and the fact that Bhasin did not have any independent right to earlier notice of the actual or potential cancellation of his contract than the six month notice period specified in the contract itself. The Supreme Court's award to Bhasin also appears out of step with the notice period in the contract, because it was assessed according to the amount of Bhasin's financial loss that could have been saved if Can-Am had answered Bhasin's enquiry honestly in August $2000 .^{22}$ This is despite the fact that Can-Am was only contractually required to provide six months' notice, and the fact that the Supreme Court stated that a breach of the duty ought to attract an award of damages on the contract measure, which is difficult to reconcile with the actual award. ${ }^{23}$

Having set out the above summary of the Supreme Court's decision, I will now proceed to explain how these points arguably make DHP an instance of Australian equitable estoppel rather than a component of contract.

\section{B. Why DHP IS Not a Claim In CONTRACT}

The Supreme Court's description of DHP as a contractual duty is difficult to justify for a number of reasons, but principally because it does not appear to operate within or conform to the ordinary rules of contract, or at least not those rules that apply at common law. The distinction between common law and equity is not often developed much in Canadian law, but in the present case such a development is necessary to make sense of DHP in relation to contract law as a whole. What I mean by this distinction being left undeveloped is that in Canadian law, there is a tendency to treat the division between common law and equity as

Bhasin, ibid at paras 30,72-73, 103 (it appears that the possibility of such a duty was first raised by counsel for Bhasin in oral argument before the Supreme Court).

Ibid at paras $100-103$.

The Supreme Court does not refer to a specific date for the purposes of its assessment, but it is clear that the assessment was made to account for the effect of Can-Am's dishonesty (ibid at paras 108-109). Recall that Can-Am's first overt act of dishonesty with respect to its intentions to effect a merger or takeover of Bhasin's agency by Hrynew and terminate Bhasin's contract was its equivocal response to Bhasin's enquiry in August 2000 (ibid at para 100). The duty of honest performance is said to fall short of a "duty of disclosure": only the express statements made in August 2000 and after with respect to the merger would constitute a violation of the duty (ibid at para 86). Bhasin, ibid at para 88 . 
inconsequential or anachronistic, and to then gloss over it. ${ }^{24}$ The particular reasons for this attitude in Canada are not entirely clear, but its outcome has quite plainly been that equity has become the deus ex machina of judicial decision-making. That is to say, it has become the filler of gaps and the plug of leaky arguments, because most often it is simply invoked in a cursory way without any explanation as to how the equity arises, how a given party's conscience is enjoined, or which principle is involved. ${ }^{25}$ In fairness, this approach, though lacking in rigour, is not disastrous in every case, but I argue in the strongest possible terms that the distinction cannot be ignored in the present case, because Bhasin cannot be understood without it.

The obvious points of conflict between DHP and orthodox contract doctrine will be examined below in order to make it clear that while DHP may affect the ordinary relations of contracting parties, it is not a part of the common law of contract.

The first aspect of DHP that puts it offside with orthodox contract doctrine is that it is expressly said to be (or impose) an obligation that is neither an express nor an implied term of the parties' contract. ${ }^{26}$ Although this may not seem immediately objectionable, it must be remembered that the rather paradoxical possibility of "extra-contractual" obligations arising in contract has been foreclosed across the Commonwealth (including Canada) for at least the last thirty years, or to be more precise, ever since the House of Lords finally rejected the doctrine of fundamental breach in Photo Production Ltd. v. Securicor Transport Ltd ${ }^{27}$ Photo Production was, of course, later adopted by the Supreme Court in Hunter Engineering Co. v. Syncrude Canada Ltd., which likewise emphasized that there was no basis for the imposition of liability for breach under a contract when that liability was excluded by the contract $^{28}$ (unless of course the exclusion clause itself was a priori unenforceable, in which case liability could arise in the orthodox way, but not otherwise). ${ }^{29}$

With Photo Production in mind, it is clear that the orthodox position is, and has been since that case, that obligations in contract are terms and no more. Thus, on this point at least, DHP appears to be clearly at odds with established doctrine. However, the conflict does not end here. As I will explain, the theoretical conflict caused by the extra-contractual imposition of an obligation goes hand in hand with two further significant and practical conflicts with established doctrine in operation.

The Supreme Court of Canada's endorsement of the New Zealand decision of my countryman President Cooke (as he then was) in Day v Mead, [1987] 2 NZLR 443 (CA), with respect to the applicability of common law concepts on limitation of damage to fiduciary claims, is indicative of this tendency or approach: Canson Enterprises Ltd v Boughton \& Co, [1991] 3 SCR 534 ("“[o]n this matter, I fully agree with Cooke P. in Day v. Mead ... that in many cases [the classification of legal or equitable] is 'a difference without a distinction"” at 577-78 [citation omitted]).

25 This is evident from Canadian judicial engagement with estoppel. See Bruce MacDougall, Estoppel (Markham: LexisNexis, 2012), § 1.36 [MacDougall, Estoppel].

Bhasin, supra note 1 at paras $74-75$.

[1980] UKHL 2, [1980] AC 827 [Photo Production].

[1989] 1 SCR 426 at 455-62, Dickson CJC [Hunter Engineering]. See also Shannon O'Byrne, "Assessing Exclusion Clauses: The Supreme Court of Canada's Three Issue Framework in Tercon Contractors Ltd v British Columbia (Transportation and Highways)" (2012) 35:1 Dal LJ 215 (noting that although Chief Justice Dickson's view and approach were opposed by Justice Wilson, who favoured retaining jurisdiction to intervene when a breach is egregious, it appears that Chief Justice Dickson's view has "carried the day" at 228). Ibid. 
The second aspect of DHP that places it in conflict with orthodox contract law is the fact that we are told that it cannot be excluded from, ${ }^{30}$ or even modified by the express terms of the parties' contract, unless the parties expressly modify the duty itself. ${ }^{31}$ Even then, its "minimum core requirements" are said to be inviolable. ${ }^{32}$ This position is likely to be alarming to many practitioners, but as mentioned above, it is hardly surprising given the Supreme Court's position that DHP does not form a part (even a fictitiously implied part) of the parties' actual agreement, and given that it "operates irrespective of the intentions of the parties." 33 The reason being that, if DHP is a contractual obligation whose existence does not depend on the parties' wills, there is no reason in principle for it to bend to the parties' wills. Instead, as an obligation clearly being imposed from above, unlike even a very fictitiously "implied" term, there is no obvious reason for it to conform to the parties' agreement. This does not make the interference in the parties' contract any more acceptable, but it further explains why DHP is more of an intrusion into, rather than an addition to, the sphere of contract doctrine: it displaces, rather than extends or harmonizes with, either the terms of individual contracts or the institution of contract as a whole. ${ }^{34}$

The third, and perhaps most worrying, aspect of DHP that sets it apart from orthodox common law contract doctrine is an extension of the second. It is the fact that the result and remedy in Bhasin seem to indicate that in addition to being immune to exclusion or amendment by the express terms of the parties' contract, DHP can, in certain circumstances, impose obligations that conflict with the express terms of a contract. ${ }^{35}$ The particular conflict in Bhasin is explored in greater detail below, but for present purposes, it involves the partial vindication of an interest that runs counter to the express language of the parties' agreement. The theoretical conflict raised by this point is evident if we remember that the contractually enforceable interests of the parties to a contract are embodied in the terms of the contract, and that valid terms cannot conflict and yet stand side by side. Inevitably, in case of conflict,

The fact that the time specified for notice of non-renewal did not prevent Can-Am from being obliged to provide an honest response earlier than it was contractually obliged to tends to indicate that the duty will be unaffected by even fairly clear limitations on parties' disclosure or notice requirements: see Bhasin, supra note 1 at paras 75-77. Contra Shannon O'Byrne \& Ronnie Cohen, "The Contractual Principle of Good Faith and the Duty of Honesty in Bhasin v. Hrynew" (2015) 53:1 Alta L Rev 1 at 31-34.

32 Bhasin, ibid at para 77. See also Neil Finkelstein et al, "Honour Among Businesspeople: The Duty of Good Faith and Contracts in the Energy Sector" (2015) 53:2 Alta L Rev 349 at 369-70; O'Byrne \& Cohen, ibid at 20 (the parties' ability to modify the duty may also vary according to the category of contract or relationship); Andrea M Bolieiro, "Bhasin v. Hrynew and the Principle of Good Faith in Contracts: Moving Towards a Modern View of Commercial Relationships" (2015) 33:4 Adv J 23 at 25. Bhasin, ibid at para 74. See also Finkelstein, ibid at 370.

It is worth noting that while Justice Cromwell (on behalf of the Supreme Court) likens DHP to preexisting doctrines in equity, saying that "[i]t operates irrespective of the intentions of the parties, and is to this extent analogous to equitable doctrines which impose limits on the freedom of contract, such as the doctrine of unconscionability," it appears that he is mindful of the distinction between common law and equity, and does not regard DHP as an equitable intrusion into common law contract doctrine, but instead takes the view that DHP is "a general doctrine of contract law that imposes as a contractual duty a minimum standard of honest contractual performance" (Bhasin, ibid [emphasis added]). This, it would seem, lends to the possibility that the Supreme Court intended for DHP to be thought of or treated as an equitable doctrine, which is the position I will advocate for. Contra Jacob Young, "Justice Beneath the Palms: Bhasin v. Hrynew and the Role of Good Faith in Canadian Contract Law" (2016) 79:1 Sask L Rev 79 (describes the effect of the Bhasin decision as an "incrementally radical' evolution" in contract law, rather than a radical departure from it at 80).

35 See Joseph T Robertson, "Good Faith as an Organizing Principle in Contract Law: Bhasin v HrynewTwo Steps Forward and One Look Back" (2015) 93:3 Can Bar Rev 811 at 845. 
one must yield. ${ }^{36}$ In its description and application of DHP, however, the Supreme Court has apparently or purportedly done away with this limitation by providing an avenue for extracontractual interests to be enforced on the same footing as those expressed and agreed to by way of contract. The practical problem that arises from such a position is that if this is correct, then parties can no longer be sure that their voluntary allocation of rights, responsibilities, and risks in contract will be final. ${ }^{37}$

This point is a cause for concern, not only on a theoretical or doctrinal level, but also at a practical level, because of the way in which this purported change may fundamentally undermine what contracts do. ${ }^{38}$ The function of contracts is to permit the allocation of risk, forward planning, and most importantly, the realization of surpluses from trade. That is, the function of contracts is to allow a mutually beneficial exchange. ${ }^{39}$ This purpose fundamentally depends on the certainty of the rights and obligations that parties accept by way of their contract, because only when obligations are clear can parties understand and price their risks, plan with confidence, and appropriately price their own obligations. ${ }^{40}$ The possibility that DHP will permit the addition, substitution, or deletion of obligations and rights in a manner inconsistent with the parties' own agreement goes to the very core of contract, and is the strongest reason as to why DHP does not fit the common law of contract. $^{41}$

In sum, it is difficult if not impossible to find a way to reconcile DHP with the fundamentals of contract doctrine. Instead, it becomes clear that DHP must be regarded as a departure from the rigours of the common law of contract. This is not to say that DHP is ultimately a negative development, but I argue that some classification other than "contract" must be found for DHP, if we are to avoid having the doctrine inflict a calamity on our understanding of the law of obligations.

GHL Fridman, The Law of Contract in Canada, 6th ed (Toronto: Carswell, 2011) at 455. See also Sable Offshore Energy Inc v Ameron International Corporation, 2008 NSSC 250, 73 CLR (3d) 91 at paras 39-41; Continental Insurance Co v Law Society of Alberta (1984), 14 DLR (4th) 256 at 262 (CA). However, some scholars are optimisic: see e.g. O’Byrne \& Cohen, supra note 31 at 27-28 (notes that uncertainty is not necessarily an unavoidable consequence of recognizing good faith obligations of this type, if limits are recognized as indicated); Kham \& Nate's Shoes No 2 v First Bank, 908 F (2d) 1351 (7th Cir 1990) ("“w]hen the contract is silent, principles of good faith ... fill the gap. They do not block use of terms that actually appear in the contract" at 1357).

38 Sina Akbari, "Against the Reductionism of an Economic Analysis of Contract Law" (2015) 28:2 Can JL \& Jur 245 at 254-56 (suggests that economic objections made with respect to good faith obligations generally can be leveled at DHP, or that DHP is tantamount to a general obligation of good faith as reflected in the United States' Restatement (Second) of Contracts (1981) or the UCC).

39 See Krish Maharaj, "Limits on the Operation of Exclusion Clauses" (2012) 49:3 Alta L Rev 635 at 636-38, 646; SM Waddams, The Law of Contracts, 6th ed (Aurora, Ont: Canada Law Book, 2010) at paras 698-99. See also LL Fuller \& William R Perdue Jr, "The Reliance Interest in Contract Damages: 1" (1936) 46:1 Yale LJ 52 (recognition of the reliance interest and reliance damages as the clearest indication of the importance of contract's planning function); Anglia Television Ltd v Reed (1971), [1972] 1 QB 60 (CA) [Anglia Television].

41 David Campbell, "Good Faith and the Ubiquity of the 'Relational' Contract" (2014) 77:3 Mod L Rev 475 (at the very least, it must be said to be out of step with contract law's traditional ethos of "selfinterest" at 483). 


\section{WHY DHP IS IN ESSENCE EQUITABLE ESTOPPEL}

\section{A. Why AND How Estoppel Is Relevant AT AlL}

Before delving into my analysis of the facts and holding of Bhasin in order to make the case for re-characterizing DHP as Australian equitable estoppel, a few words are necessary regarding promissory estoppel in Canada and Australia, and the significance of the difference between them.

\section{PROMISSORY ESTOPPEL IN CANADA}

It is relatively straightforward to say that promissory estoppel forms a part of Canadian law. It is, however, much less straightforward to explain what Canadian promissory estoppel is. As Bruce MacDougall relates in his treatise on the subject, decisions on point from the Supreme Court of Canada are generally "marked by their brevity and lack of engagement with each other," and none provide a sustained and comprehensive examination of the subject. ${ }^{42}$ Conflicting views from lower courts also do not help matters. Nonetheless, certain general characteristics can be set out.

The test for promissory estoppel in Canada has been expressed in various ways, but the test proposed by MacDougall likely captures essential qualities of the doctrine as Canadian courts have applied it. The factors that ought to be present in order to raise the estoppel are:

(a) Legal Relationship - the existence of a legal relationship, usually between the parties, but at least one where the promisor has the benefit of rights or some other stipulation that has an impact on the promisee;

(b) Assurance or Promise - words or conduct by the promisor clearly constituting a promise or an assurance to the promisee that the use of the promisor's rights or some other legal stipulation will be altered in some way;

(c) Reliance - reliance by the promisee on this promise or assurance of the promisor;

(d) Detriment - detriment by the promisee associated with this reliance, including costs already incurred and including negative consequences if the promisor were allowed to resile from his or her promise or assurance; [and]

(e) Equitable Considerations - the basis of the doctrine is in equity and it will only operate where the considerations of fairness (or even unconscionability) demand it and where equitable considerations do not militate against it. ${ }^{43}$

Of the above factors, the most important for present purposes is the requirement of promise or assurance. I say this because when this aspect of the test is applied to Bhasin, it becomes clear that an attempted resolution of Bhasin on the basis of Canadian promissory 
estoppel must be a prima facie non-starter, given that nothing so explicit as a "promise" appears to have been made in the case. ${ }^{44}$ In addition to this, two further aspects (and limitations) of Canadian promissory estoppel are also relevant. These are, first, the applicable measure of relief, and second, the limited ability of parties to raise promissory estoppel in their favour.

As to the first aspect, it is clear in Canada that the measure of relief will most often equal the value of the promised performance. ${ }^{45}$ Given the emphasis on promise or assurance as a prerequisite for estoppel to be raised, this result is understandable. A lack of flexibility is a concern, however, in cases like Bhasin where the "promisee" did not have a sound basis for recovering an amount of that value. Readers may remember that the automatic renewal of Bhasin's contract with Can-Am was always explicitly subject to refusal on notice, which rendered any award equal to the value of a renewed contract problematic, and rendered promissory estoppel difficult to apply. This may explain the apparent reticence of Canadian courts to undo the second of the two limitations referred to above and expand the doctrine's application.

The second limitation relates to the "status" of promissory estoppel in Canadian law. Although some might disagree, it appears clear for the moment that promissory estoppel in Canada remains a shield and not a sword. ${ }^{46}$ That is to say that although, on some more liberal interpretations, it may supply a missing ingredient for a recognized cause of action, Canadian promissory estoppel is not a cause of action in and of itself. ${ }^{47}$ As such, it may be better understood as providing access to relief from obligations that would otherwise exist, rather than creating remedial obligations. Unfortunately though, this renders Canadian promissory estoppel fundamentally unhelpful to a plaintiff such as Bhasin because it means, for the moment at least, that Canadian promissory estoppel cannot provide a remedy.

\section{The MODERn Australian DOCTRINE}

By contrast to what might be called the "orthodox" Canadian approach, a different, more expansive approach to promissory estoppel, now styled as "equitable estoppel," has been

Bhasin, supra note 1 at para 12 (Can-Am is said to have responded "equivocally" to Bhasin's inquiries in August 2000 with respect to a merger between his agency and Hrynew's, which appears to fall short of the standard articulated by MacDougall - that is, words or conduct by the promisor clearly constituting a promise or assurance). See also MacDougall, Estoppel, ibid ("[t]he doctrine is not applicable unless there is a clear and unequivocal statement that amounts to a promise or assurance," \$ 5.165); MacDougall, Estoppel, ibid ("[w]hile it is possible that the promise or assurance can be implied or made through silence, these contexts will be reasonably rare because it may be difficult to satisfy this requirement of clarity and unambiguity in such contexts," $\S 5.173)$.

45 MacDougall, Estoppel, ibid, §§ 5.275-76, 5.279, 5.284 (notes that the current Canadian approach to relief flowing from promissory estoppel is to make good the promise, with little to no apparent scope for a court to tailor the relief, and it is uncertain as to whether promissory estoppel may be used as a cause of action in Canada).

46 Bhasin, supra note 1 at para 88 (it is presently uncertain as to whether promissory estoppel may be used as an independent cause of action in Canada, but the Supreme Court's remarks tend to suggest that it is not). But see Robichaud v La Caisse populaire de Pokemouche Ltée (1990), 105 NBR (2d) 227 (CA); NAV Canada v Greater Fredericton Airport Authority Inc, 2008 NBCA 28, 329 NBR (2d) 238 at para 29 (the sword versus shield distinction is strongly criticized by Justice Robertson).

47 See Combe v Combe, [1951] 2 KB 215 at 220 (CA), Denning LJ [Combe]. See also Amalgamated Investment \& Property Co Ltd (In Liquidation) v Texas Commerce International Bank Ltd, [1982] 1 QB 84 at 131 (CA), Brandon LJ [Texas Commerce]; Erickson v Jones, 2008 BCCA 379, 299 DLR (4th) 465, Chiasson JA [Erickson]. 
developed in Australia. ${ }^{48}$ The modern Australian doctrine of equitable estoppel finds its origin in the 1988 High Court of Australia decision in Waltons Stores (Interstate) Ltd. v. Maher ${ }^{49}$ In this case, Justice Brennan proposed a test for the new cause of action based on the following six factors:

(1) The plaintiff assumes a particular legal relationship exists with the defendant, from which the defendant is not free to withdraw;

(2) the defendant induced that assumption;

(3) the plaintiff acts (or refrains from acting) in reliance on the assumption;

(4) the defendant knew or intended the plaintiff to do so;

(5) the plaintiff will incur a detriment if the assumption is not fulfilled; and

(6) the defendant fails to act to avoid the detriment to the plaintiff. ${ }^{50}$

The basic facts of Waltons Stores involve pre-contractual negotiations for the lease of a retail location by the defendant, Waltons, from the plaintiff, Maher. Negotiations between the parties commenced with the understanding that the present building on site was unsuitable for Waltons' business, and that it would have to be demolished and replaced. Further, the parties also understood that Waltons' planned timeline for occupation would require Maher to commence demolition and reconstruction immediately if the site were to be available in time. On that basis, Waltons' solicitors advised Maher's solicitor that they had a verbal agreement to the terms negotiated, and that any objection to particular terms would be communicated forthwith. Otherwise, it appeared that Waltons would formally exchange signed contracts on the terms agreed once the documents were ready, and Maher for his part went ahead with demolition and reconstruction in the meantime. Unfortunately, once the documents were ready for exchange, Waltons purported to renege and refused to exchange the signed contracts as Maher had been led to believe they would, despite the fact that redevelopment of the site to fit Waltons' specifications was well under way. ${ }^{51}$

Waltons' refusal to complete as promised prompted Maher's suit against it, but it also gave rise to a seemingly insurmountable difficulty with respect to Maher's claim. The challenge faced by Maher was that under New South Wales law, the exchange of signed contracts was a prerequisite for the formation of contracts in respect of land. ${ }^{52}$ As such,

The name "equitable estoppel" is more appropriate for the Australian doctrine because it is capable of responding to communications other than explicit promises, which makes referring to it as "promissory estoppel" potentially misleading, even though promises can be, and are, used as the basis for raising estoppel. As such, if the Australian approach is to be adopted, as I argue it should, then I would suggest the name should be adopted as well. Although, I hasten to add that I will propose modifications to the doctrine should it be adopted, and one of these will be to refrain from allowing equitable estoppel to subsume all other categories of estoppel, including proprietary estoppel and estoppel by representation, and to instead have it only occupy the ground presently taken by promissory estoppel in Canada. See MacDougall, Estoppel, supra note 25, $\S 1$ 1.35-1.36.

[1988] HCA 7, 164 CLR 387 [Waltons Stores].

Ibid at $428-29$.

Ibid at 389-95.

Ibid at 393. 
Maher could not mount an action for breach, and thus could not pursue the ordinary remedy of expectation damages for breach, or the more extraordinary remedy of specific performance. Likewise, an action for estoppel by representation appeared unfounded because the "statement" made by Waltons was a representation as to the future: that is, a mere claim that it would exchange contracts, not a statement of present fact as required by this branch of estoppel..$^{53}$ This left Maher and the High Court with few if any options, as no cause of action otherwise appeared available; promissory estoppel had only been available as a defence up to this point. The High Court of Australia's response, of course, was to permit Maher to use promissory estoppel as a cause of action, and to allow Maher to thereby hold Waltons to its "promise" to exchange contracts and form the contract. This was the only way to remedy the detriment that would otherwise be suffered by Maher if Waltons did not follow through.

Since the High Court's decision in Waltons Stores, its test for equitable estoppel has been accepted or applied in a number of Australian decisions. ${ }^{54}$ Though the Waltons Stores test is relatively clear, these decisions and others have clarified certain points as to its application that merit elaboration because of their particular applicability to cases like Bhasin.

The first clarification is the fact that the test does not call for a statement amounting to a specific promise.$^{55}$ In fact, it does not even appear to call for a direct statement to the plaintiff at all. Instead, as in Waddell, it may well be that the statements that induce the plaintiff's assumption are made indirectly — they are made to third parties either in the plaintiff's presence or out of it, so long as there was reason to believe that the plaintiff would learn of them. ${ }^{56}$ This latter aspect of the doctrine's application is not necessarily novel though, as the same approach is already taken to third party communications in Canada with respect to estoppel and misrepresentation. ${ }^{57}$ The larger point is still significant in light of the particular facts of Bhasin, however, where no explicit promise appears to have been made, because it indicates that there is scope for this variety of estoppel to respond to a wider array of potential circumstances than the term "promissory estoppel" would seem to imply.

$53 \quad$ Ibid at 397-89. See also MacDougall, Estoppel, supra note 25, $§ 4.75$.

54 See Verwayen, supra note 2 (it was Chief Justice Mason in this decision that changed the name of the Australian doctrine from "promissory estoppel" to "equitable estoppel," and purported to merge the categories of estoppel into this one doctrine); Foran $v$ Wight, [1989] HCA 51, 168 CLR 385; Giumelli v Giumelli, [1999] HCA 10, 196 CLR 101 [Giumelli]. See also Waddell v Waddell, [2012] NSWCA 214, 292 ALR 788 at paras 40, 66 [Waddell]; Settlement Group Pty Ltd v Purcell Partners (A Firm), [2013] VSCA 370, 2013 WL 6624254 (WL Aus) at paras 43-44, 124.

55 See Galaxidis v Galaxidis, [2004] NSWCA 111, 2004 WL 1183356 (WL Aus) at paras 91-93; Australian Crime Commission v Gray \& Anor, [2003] NSWCA 318, 2003 WL 25882087 (WL Aus) at paras 179-196; Legione v Hateley, [1983] HCA 11, 152 CLR 406 ("[t]he requirement that a representation as to existing fact or future conduct must be clear if it is to found an estoppel in pais or a promissory estoppel does not mean that the representation must be express" at 438). I note that the use of clear terminology may be difficult with respect to equitable estoppel because the Australian doctrine responds to a wider range of communications than those that would qualify as either "representations," as that term is understood in a technical legal sense, or what we might otherwise understand as "promises" in the ordinary sense of the word. As such, from this point onward the terms "statement" or "communication" will be used to refer to communications that could allow a party to raise an equitable estoppel in their favour, in the hope that this term will be broad enough to convey the true scope of the doctrine's application.

$56 \quad$ Waddell, supra note 54 at para 64.

57 MacDougall, Estoppel, supra note 25, $\S \S 4.432,5.95$; Bruce MacDougall, Misrepresentation (Toronto: LexisNexis, 2016), § 3.62 [MacDougall, Misrepresentation]. 
The second clarification is that the test in Waltons Stores (and the subsequent case law) has not taken a strict approach to the question of knowledge or intention, and that the former is quite clearly interchangeable with the latter. ${ }^{58}$ Again, as with the point relating to third party communications, Canadian promissory estoppel is in agreement with authority from Australia on this point. ${ }^{59}$ This flexible approach notwithstanding, it is evident that this branch of estoppel distinguishes between culpable and non-culpable representations, whereas DHP, as described by the Supreme Court, does not. Further, the approach taken is alive to the distinction between intent and motivation, as I will discuss below.

The third significant clarification of the Australian doctrine relates to remedies. Though not adverted to directly in the test above, it is clear that the estoppel arises in equity in order to undo the detriment to the plaintiff ${ }^{60}$, and that the award should be limited according to the scope of the detriment (the Detrimental Reliance Approach). ${ }^{61}$ Under the Australian doctrine, this can be done by the court in two ways. Each is generally consistent with Canadian law, but require some elaboration in order to make sense.

The first option is that the court may impose a temporal limit with respect to the relief or remedy it provides, by either explicitly limiting the period to which the award applies, or by permitting the enjoined party to revert to its prior position with notice. ${ }^{62}$ The second is that the Australian doctrine permits what can be described as a "substantive" limit on the award, which means that the court may, in its discretion, limit the "scale" or "value" of the award, even if it does not wish to modify the time or period to which the award will apply. ${ }^{63}$ The best example of this approach to substantive limitation might be the decision to award a life estate or lesser interest in land in lieu of a fee simple. ${ }^{64}$ I note that the possibility of imposing the first type of limitation, a temporal limitation, on an award made under promissory estoppel is already well established in Canada. ${ }^{65}$ The second, however, is not, although the

\section{Ibid.}

See Owen Sound Public Library Board v Mial Developments Ltd (1979), 26 OR (2d) 459 at 467 (CA) [Owen Sound].

Sidhu v Van Dyke, [2014] HCA 19, 308 ALR 232 at paras 80-82 [Sidhu]. See also Grundt v Great Boulder Pty Gold Mines Ltd, [1937] HCA 58, 59 CLR 641 at 674-75, Dixon J [Grundt].

I note that with respect to the assessment of remedy, there has been something of a move away from the "minimum equity approach" articulated in Waltons Stores, supra note 49, and by the minority in Verwayen, supra note 2, in favour of greater enforcement of promises and expectations. However, this change appears to be more of a change in form rather than substance in reasoning; more recent decisions, including Sidhu, ibid and Giumelli, supra note 54 appear to have merely indicated that the relief necessary to prevent detriment to the plaintiff will usually be the making good of the plaintiff's expectations, not that expectations must be made good in every case. It is also worth noting that rather than grant a lesser remedy, the Court in Waltons Stores specifically enforced the defendants promise, whereas the Court in Giumelli actually did not. See Waltons Stores, ibid at 404-405, 419; Verwayen, ibid at 415-16, 429; Giumelli, ibid (I note that the conveyance of a promised piece of land was denied in Giumelli in order to "avoid injustice to others ... and to avoid relief which went beyond what was required for conscientious conduct by [the promisors]" at para 50 [emphasis added]); Sidhu, ibid ("[w] hile it is true to say that "the court, as a court of conscience, goes no further than is necessary to prevent unconscionable conduct,' where the unconscionable conduct consists of resiling from a promise or assurance which has induced conduct to the other party's detriment, the relief which is necessary in this sense is usually that which reflects the value of the promise" at para 85 [footnote omitted]). But see JD Heydon, MJ Leeming \& PG Turner, Meagher, Gummow and Lehane's Equity: Doctrines and Remedies, 5th ed (Chatswood, NSW: LexisNexis Butterworths, 2015) at para 17-285.

This has been the case with promissory estoppel since at least Central London Property Trust Ltd v High Trees House Ltd (1946), [1947] 1 KB 130, Denning J.

See Heydon, Leeming \& Turner, supra note 61 at para 17-285.

See Alexander $v$ Jansson, [2010] NSWCA 176, 2010 WL 2959987 (WL Aus) at paras 18-21.

See MacDougall, Estoppel, supra note 25, §§ 5.298-5.301. See also Saskatchewan River Bungalows Ltd v Maritime Life Assurance Co, [1994] 2 SCR 490 (here discussed as waiver). 
approach is available in Canadian law with respect to awards made in successful cases of proprietary estoppel. ${ }^{6}$ As such, the overall approach to providing relief under the Australian doctrine would seem to be generally consistent with Canadian authority on estoppel.

Having lauded the remedial flexibility of the Australian doctrine above, I should note that the appropriate measure may not infrequently equal the value of the relevant "statement" or "promise," as it did in Waddell and Waltons Stores. ${ }^{67}$ Nonetheless, as with all remedies for equitable claims, the measure applied will be that which is apt to respond to the equities of the case. As I will explain, this appears to be much more in keeping with the Supreme Court's approach to remedy in Bhasin than the contract measure that the Supreme Court ostensibly applied.

The fourth and penultimate clarification I wish to mention, although made clear by Waltons Stores itself and not clarified by later case law, is that equitable estoppel is in itself a cause of action. ${ }^{68}$ This point is important and bears emphasis because, as noted above, promissory estoppel in Canada cannot presently found a claim on its own. This is a fact that the Supreme Court referred to in Bhasin, and which is the most simple and obvious reason as to why Canadian promissory estoppel cannot currently assist a claimant like Bhasin or a court faced with a claim based on such facts. ${ }^{69}$

The fifth and final clarification relates to what "estoppel" now means in a terminological sense, given the way in which equitable estoppel operates. The traditional meaning is of course literally "to stop," which is apt in those cases in which an estoppel is raised in order to prevent a party's denial of some statement made by them to the other, and to thereby force the party estopped to conduct his affairs "subject to the qualification which he himself has so introduced." ${ }^{, 70}$ In this sense, estoppel can, and historically has, been understood as working to make the statement true, rather than providing a remedy to the injured party for the statement being false. ${ }^{71}$ The latter of these two activities historically has been the province of actions in tort for misrepresentation and deceit, rather than estoppel. ${ }^{72}$

In light of the changes brought about by both equitable estoppel's availability as a cause of action and the Detrimental Reliance Approach to remedy (which does not necessarily require that the defendant live up to a statement in its entirety), it appears that the above characterization of estoppel as preventing a partying from "denying the truth" of their statements may not fit estoppel of this kind. It may be fitting to say, though, that "estoppel" in equitable estoppel does not prevent the denial of truth so much as it prevents the denial of responsibility for the detriment suffered by the innocent party. This view is consistent with equity's approach to intervention in common law matters generally, given that equity acts principally to prevent injustice that would otherwise result from a party's unmeritorious

See MacDougall, Estoppel, ibid, § 6.202. See also Maritime Telegraph and Telephone Co v Chateau LaFleur Development Corp, 2001 NSCA 167, 199 NSR (2d) 250 at para 38 [Maritime Telegraph].

Waltons Stores, supra note 49 at 426-30, 463-64; Waddell, supra note 54 at paras 66-75.

Waltons Stores, supra note 49 at $413-18$.

Bhasin, supra note 1 at para 88.

Combe, supra note 47 at 220.

MacDougall, Estoppel, supra note 25, §§ 1.19-1.20; MacDougall, Misrepresentation, supra note 57 at para 1.172.

Ibid. 
insistence on their strict rights. ${ }^{73}$ This "insistence," in cases like Bhasin for instance, entails a denial of responsibility for detriment that has been knowingly caused. As such, the notion that "estoppel" means "to stop" may still very much fit "estoppel" as used in equitable estoppel, even though the court's refusal is not as literal, and instead appears to mean that the court will stop a party from denying responsibility for a detriment flowing from their statements, even though their strict rights at law might have otherwise allowed them to do so.

\section{Why TAKe Note of Australian Authority?}

From the foregoing, it can be said that there are potentially three significant differences between Canadian promissory estoppel and Australian equitable estoppel. The first of these is that Australian law permits a wider range of "statements" to potentially found such a "promissory type" estoppel than Canadian law. ${ }^{74}$ The second is that Australian law appears to permit greater remedial flexibility for equitable estoppel than the equivalent Canadian law. ${ }^{75}$ And the third, and most important, is that Australian law explicitly recognizes that equitable estoppel is itself a cause of action, whereas Canadian law does not yet recognize any comparable claim. ${ }^{76}$

As I will demonstrate, these differences between Canadian and Australian doctrine are significant for present purposes because they render the Australian doctrine more readily applicable on its face to cases like Bhasin than the analogous Canadian doctrine. This in short is why I argue that Bhasin could readily and reasonably be understood, or recharacterized, as a case of equitable estoppel, particularly in light of the Supreme Court's award, if Canadian law were to embrace the Australian position. At the outset I will concede that the proposal to adopt the Australian position, subject to modest modifications, is a call for more than insubstantial reform to Canadian equity on estoppel. However, as those familiar with the subject will know, it is possible to argue that the points of difference between Canadian and Australian doctrine are not so much evidence of inconsistency or disagreement as they are proof of a lack of clarity in Canadian law. As such, and particularly in light of my conclusion in Part II.B, above (that the Supreme Court's own proposal fails for want of consistency with the general schema of contract law), I suggest that a moderate reform to Canadian promissory estoppel, or DHP itself to attain the same end result, is an easier and more fruitful path for Canadian law to pursue than the one chosen by the Supreme Court.

Crabb v Arun District Council (1975), [1976] 1 Ch 179 at 187 (CA), Lord Denning MR [Crabb]. See also Heydon, Leeming \& Turner, supra note 61 at para 3-250. See generally FW Maitland, Equity, 2nd ed by AH Chaytor \& WJ Whittaker, revised by John Brunyate (Cambridge: Cambridge University Press, 1936).

74 For an explanation of the applicable Australian and Canadian law, see the text accompanying notes 44, 55.

75 For an explanation of the applicable Australian and Canadian law, see the text accompanying notes 45, 61.

76 For an explanation of the applicable Australian and Canadian law, see the text accompanying notes 46, 54. 


\section{B. How Bhasin CAN Be Viewed AS A CASE OF EQuitable ESTOPPEL}

I have explained how DHP does not fit with the established requirements and restrictions inherent in contract law and contract claims. Put simply, this is because Bhasin's claim did not arise from the violation of an agreed right, which makes it unlike any orthodox contract claim, because contract claims subsist only where the infringement of a particular contractual, agreed-upon right can be shown. ${ }^{77}$ What I have not said is why or how this makes DHP look more like equitable estoppel. In short, I argue that equitable estoppel is the only apt characterization for Bhasin, given that the Supreme Court's intervention can only be justified on the basis that Can-Am's insistence on its strict rights was unfair. My conclusion on this point, and for the article as a whole, undoubtedly rests on a number of intuitions "more subtle than any articulate major premise." sound will become apparent as its basis is considered explicitly below.

\section{ESTOPPEL AND THE BASIS FOR INTERVENTION}

The simplest reason for regarding DHP as more akin to equitable estoppel than a claim in contract is because it sidesteps the parties' agreed contractual rights and obligations, and instead focuses on the quality of their individual acts. ${ }^{79}$ Although it is not readily apparent, what the Supreme Court has attempted to achieve in doing this, as stated above, is to reverse the effect of the defendant's inequitable or unconscionable insistence on his or her rights, ${ }^{80}$ which is the essence of equity as a jurisdiction, and the essential function of an action in

If it were otherwise, there would be no need to imply obligations of good faith in order to make actions contrary to the spirit of an agreement (rather than its letter) actionable by the injured party. As do all legal opinions in truth: see Lochner v New York, 198 US 45 at 76 (17 April 1905), Holmes $\mathrm{J}$, dissenting.

79 Contract, strictly speaking, has (at least since its heyday in the 19th century) not traditionally had much concern for the vice or virtue of the parties, what with contracts being relatively "amoral" devices or means to reach permitted ends (that is, any end that is not otherwise forbidden). See Printing and Numerical Registering Company v Sampson (1875), LR 19 Eq 462 (CA), Jessel MR:

It must not be forgotten that you are not to extend arbitrarily those rules which say that a given contract is void as being against public policy, because if there is one thing which more than another public policy requires it is that men of full age and competent understanding shall have the utmost liberty of contracting, and that their contracts when entered into freely and voluntarily shall be held sacred and shall be enforced by Courts of justice. Therefore, you have this paramount public policy to consider - that you are not lightly to interfere with this freedom of contract (ibid at 465).

In Bhasin for example, this was done by reversing the effect of Can-Am's insistence that it had a right not to respond honestly to Bhasin's inquiries about renewal or termination of their contract until the date Can-Am was required (in their contract) to give notice of termination. See Hughes $v$ Metropolitan Railway Co, [1877] UKHL 1, [1877] 2 AC 43, Cairns LC:

$[\mathrm{I}] \mathrm{t}$ is the first principle upon which all Courts of Equity proceed, that if parties who have entered into definite and distinct terms involving certain legal results ... afterwards by their own act or with their own consent enter upon a course of negotiation which has the effect of leading one of the parties to suppose that the strict rights arising under the contract will not be enforced, or will be kept in suspense, or held in abeyance, the person who otherwise might have enforced those rights will not be allowed to enforce them where it would be inequitable having regard to the dealings which have thus taken place between the parties (ibid at 448 [emphasis added]).

See also Waltons Stores, supra note 49, Mason CJ and Wilson J ("[t]rue it is that in the orthodox case of promissory estoppel, where the promisor promises that he will not exercise or enforce an existing right, the elements of reliance and detriment attract equitable intervention on the basis that it is unconscionable for the promisor to depart from his promise, if to do so will result in detriment to the promisee" at 401). 
equitable or promissory estoppel. ${ }^{81}$ The early decisions in the history of equitable estoppel referred to the acts of the estopped promisor as giving rise to "an equity" in the plaintiff, rather than an estoppel. ${ }^{82}$ Note that this is still the usual language of proprietary estoppel, and courts applying that doctrine will explicitly weigh the "equities" when determining whether to, and what extent to, intervene. ${ }^{83}$ An "equity" in this latter sense is akin to a power to seek relief, as in the action for promissory estoppel, but not a right to relief itself, which is exactly how the plaintiff's claim was treated in Bhasin.

Having set the stage for an analysis of Bhasin as a case of equitable estoppel, I will now advance the case. The Supreme Court in Bhasin did compare DHP to promissory estoppel and estoppel by representation, but was quick to distinguish them. ${ }^{84}$ Unlike the two forms of estoppel, DHP does not require that the defendant intend that his or her representation be relied on.$^{85}$ In this respect, my thesis runs contrary to the Supreme Court's overt obiter. As we shall see from a further examination of the remedial outcome of the case, however, the actual award indicates an apparently different rationale for the outcome.

\section{The EXTENT OF DETRIMENTAL RELIANCE BUT NOT NECESSARILY THE EXPECTATION}

Without a doubt, the award in Bhasin is its most surprising feature and, in my opinion, the key to explaining what DHP really means. To explain, I begin my analysis with the generally, uncontroversial proposition that "rights" as well as "equities" (or more generally, juridically recognized "interests") ought, in theory, to define the nature and the extent of the remedies that are granted to vindicate them. Likewise, and perhaps more controversially, I also accept the inverse proposition that if interests "ought" to define remedies in theory, then a fortiori remedies granted to vindicate a juridically recognized "interest" must define the nature or extent of that "interest" or the extent to which it is recognized in practice, and thus, the extent to which it is "real." As such, I take the view that it is possible to trace and outline the nature and extent of the "claim" and cause of action in this case by reasoning backward from the nature of the award and from the factors that shaped it.

\section{a. Bhasin's Award Was Not Made to the Claimed Measure}

In addition to distinguishing DHP from promissory estoppel, the Supreme Court also distinguished it from related tortious causes of action, such as civil fraud, on the basis that

See Crabb, supra note 73, Lord Denning MR:

The basis of this proprietary estoppel — as indeed of promissory estoppel - is the interposition of equity. Equity comes in, true to form, to mitigate the rigours of strict law. The early cases did not speak of it as "estoppel." They spoke of it as "raising an equity." If I may expand what Lord Cairns L.C. said in Hughes v. Metropolitan Railway Co. (1877) 2 App.Cas. 439, 448: "it is the first principle upon which all courts of equity proceed," that it will prevent a person from insisting on his strict legal rights - whether arising under a contract, or on his title deeds, or by statute - when it would be inequitable for him to do so having regard to the dealings which have taken place between the parties (ibid at 187-88).

See also Waltons Stores, supra note 49 at 401, Mason CJ and Wilson J; Waltons Stores, ibid at 416-17, Brennan J.

Crabb, ibid at $187-88$.

Maritime Telegraph, supra note 66 at para 38. See also Erickson, supra note 47.

Bhasin, supra note 1 at para 88.

Ibid. 
DHP supports a claim for relief on a contractual rather than tortious measure. ${ }^{86}$ Although not explicit, this position would also further distinguish DHP from promissory estoppel, given that the contractual measure (that is, the measure of the expectation) is not necessarily the measure applied in cases of promissory estoppel. ${ }^{87}$ As suggested above, however, the remedy in this case tells a different story than the rhetoric used.

The relief actually provided in Bhasin was measured according to the difference between Bhasin's position after the cancellation of his contract (that is, after suffering the total loss of his business), and the position that Bhasin would have been in had Can-Am been honest about its intention to force a merger or to effect a takeover by way of cancelling his contract. ${ }^{88}$ Clearly, this is not a conventional damages award on the contract measure, nor, as I will argue, is it really an award for breach of contract at all. As I will explain below, the first obvious point of departure is the focus of the assessment, which appears to have nothing to do with providing the "benefit of the bargain" or putting Bhasin in the position he would have been in had the contract been performed. ${ }^{89}$

While it is true that compensatory damages may be granted for breach of contract where a plaintiff has suffered an actual "out of pocket" loss as a consequence of defective performance, and that such damages will by necessity focus upon the plaintiff's actual incurred loss, it is expectation damages that are thought of first and foremost as the contract measure. ${ }^{90}$ In the present case, Bhasin's loss was ultimately caused by Can-Am's decision to cancel his contract, which in the end amounts to the loss having been caused by Can-Am's failure to live up to the expectations it had dishonestly encouraged. If a remedy were to be provided for this conduct on the contract measure (assuming that there ought to be such a remedy at all $){ }^{91}$ clearly it ought to be to give effect to Bhasin's expectations. Yet this was not done, because Bhasin was expressly denied the value of a renewed contract. ${ }^{92}$ Instead, Bhasin was only awarded the value of a reduced loss, which, if anything, would appear closer to the tort measure that the Supreme Court explicitly disavowed, and would also appear to award Bhasin damages for having made a bad bargain, which runs contrary to the first principles of relief in contract. ${ }^{93}$

To expand on the last point, although it is not often explicitly said, it is clear that in an action for breach of contract, no damages will be payable if the contract would have been

86 Ibid; Waddams, supra note 39 at para 698 (the general rule in contract is, of course, that a plaintiff is entitled to be put into the position he or she would have been in had the contract been performed, or in other words, to recover the loss of his or her bargain). See also Harvey McGregor, Martin Spencer \& Julian Picton, McGregor on Damages, 19th ed (London, UK: Sweet \& Maxwell, 2014) at para 22-003 (the rule in contract may be contrasted with the rule in tort that a plaintiff should be restored to the status quo ante).

Heydon, Leeming \& Turner, supra note 61 at para 17-285.

Bhasin, supra note 1 at paras 108-109.

See Stephen A Smith, Atiyah's Introduction to the Law of Contract, 6th ed (Oxford: Oxford University Press, 2005) at 399 (I note that the contract measure can be thought of as synonymous with the expectation measure); McGregor, Spencer \& Picton, supra note 86 at para 4-002 (loss of bargain, that is, expectation, is the normal measure of damages in contract).

Ibid.

91 It is difficult to see how this is possible unless the Supreme Court were to deny the effect of the cancellation provision by way of an estoppel, for instance.

Bhasin, supra note 1 at para 90.

C\&P Haulage (A Firm) v Middleton, [1983] EWCA Civ 5, [1983] 3 All ER 94 at 98-100, Ackner LJ. See also Bowlay Logging Ltd v Domtar Ltd (1978), 87 DLR (3d) 325 at 332-33 (BCSC), Berger J [Bowlay]; Fridman, supra note 36 at 691-92. 
unprofitable for the plaintiff in any event. ${ }^{94}$ This holds even if the plaintiff's claim is made on the reliance measure, because reliance in contract is simply a proxy for expectation when it is otherwise impossible to assess what the plaintiff's expected benefit or gain under a contract would have been. ${ }^{95}$ Therefore, there is every reason to reject the view that Bhasin was a case involving a contract action, given that Bhasin's loss arose in large part because of the ordinary operation of the contract itself; this is not enough to found a contract claim. Note by contrast, however, it is clear that causes of action outside of contract can provide remedies irrespective of whether a given contract was a good or bad bargain. For example, the action for negligent misrepresentation may sound in damages, even if the loss under the contract was unconnected with the misrepresentation that led to the contract in question. ${ }^{96}$ As such, it appears more likely than not that some other cause of action will provide a more plausible explanation for the award in Bhasin than any possible action for breach.

If the foregoing is correct, and it is the case that the Supreme Court's rhetoric does not adequately explain its decision, this leaves a rather obvious gap in our understanding of DHP. In lieu of an explanation for it, I will propose my own.

\section{b. So, What Is It Then?}

I have already stated above that the measure of Bhasin's award appears closer to the measure available in tort, which would of course suggest (according to the logic of my introduction in Part III.B.2.a., above) that DHP is at least partly tortious in nature. However, this is not a possibility that I will consider at length in the present article because it is in fact the characterization that I hope to propose in a companion article to follow this piece. With tort and contract excluded for present purposes, the last, best option, in my opinion, is equity, acting through the mechanism of "equitable estoppel."

As I explain further below, two key aspects of the damages award in Bhasin justify the conclusion that DHP protects the same "interests" as equitable estoppel, and that DHP is thus its analogue, irrespective of the name. The first aspect is the Supreme Court's focus on the degree of Bhasin's reliance upon Can-Am's communications when assessing the quantum of the award. ${ }^{97}$ The second is that the Supreme Court expressly limited the award to cover only losses that could have been avoided if Can-Am had not misled Bhasin prior to its decision to cancel Bhasin's contract; in other words, it denied recovery for losses that arose after Can-Am had neutralized the effect of its earlier misleading communication by providing Lloyd's Rep 47 at paras 27-35; Commonwealth of Australia v Amann Aviation Pty Ltd, [1991] HCA 54, 174 CLR 64 at 85; Bowlay, ibid at 334-35; L Albert \& Son v Armstrong Rubber Co, 178 F (2d) 182 at 189 (2nd Cir 1949), Hand CJ.

Ibid.

96 The assessment of damages for negligent misrepresentation may be affected by whether a resultant contract was a good or bad bargain, but damages are not excluded on the basis that the contract was a poor one; see BG Checo International Ltd v British Columbia Hydro and Power Authority, [1993] 1 SCR 12, La Forest and McLachlin JJ ("[t]he assessment of damages in a Rainbow situation could be lower or higher than the contract damages depending on whether the contract was a good or bad bargain" at 40), citing Rainbow Industrial Caterers Ltd v Canadian National Railway Co, [1991] 3 SCR 3 .

97 Bhasin, supra note 1 at paras 108-11. 
rightful notice of termination under the contract. ${ }^{98}$ This ability to end one's "duty" by giving adequate notice is very characteristic of equitable estoppel.

The Supreme Court's focus on reliance in assessing Bhasin's award is telling because in measuring the award according to the extent to which Bhasin could permissibly rely on CanAm's communications, the Supreme Court adopted a measure that appears to be somewhat in-between tort (compensation ex ante) and contract (expectation ex post). Although, in reality, this measure is quite distinct from these because, unlike the latter two, this "reliance measure," and the "reliance interest" it protects, ${ }^{99}$ does not appear to be specifically concerned with property. Instead, the "reliance measure" (Honest Reliance Measure) adopted appears concerned with protecting reasonable expectations of fidelity, whereas the "compensation measure" and the "expectation measure" are concerned with protecting that which a party has, and that which he or she hopes to have - matters of a different kind from our expectations of people and their ethics. ${ }^{100}$ If my interpretation of the Supreme Court's decision is correct, the Supreme Court's award begins to appear far more rational because it no longer appears to be contrary to the rules of relief in contract, as I will explain, since it no longer runs afoul of the parties' actual contract at all.

The principal difficulty with envisioning DHP as a creature of contract is that if the cause of action for breach is principally concerned with protecting the extant or expected property interests of the plaintiff, which I argue it is, then it clearly had little to offer Bhasin. The reason being that without modification of the parties' contract, Bhasin apparently had no basis to assert an enforceable expectation that his contract would continue past its current term. Likewise, the termination provision in the parties' contract makes it difficult to comprehend how it was that Bhasin could assert a present or future property interest in his business worthy of protection, when this interest had always been subject to the possibility of cancellation, the very harm about which Bhasin complained. As such, it is difficult to conceive of how a claim relying upon the orthodox measure in contract (or in tort for that matter) could have vindicated the alleged infringement of Bhasin's interest under the contract, given that (as just explained) Bhasin had no interest to protect as per the terms of the contract itself. If, however, it is not Bhasin's extant or expected property interest that is being vindicated, then conflict between the award for breach of DHP and the parties' contract need not occur, and does not occur. Instead, because the monetary relief provided to Bhasin only pertains to loss that could have been avoided but for his reliance on Can-Am's misleading statements, it only vindicates his interest in honesty and fair dealing. It does not, nor attempts to, vindicate any alleged expectation or compensation interest in Bhasin's

Ibid at para 90 .

I note, of course, that the notion of a "reliance interest" or "reliance measure" in contract damages is far from new. However, the interest or measure first described by that name by LL Fuller and William Perdue means something other than, and different from, what it is I am referring to. Fuller and Perdue used these terms to describe a party's interest in being able to rely on a contract when managing or organizing their affairs, whereas what I have described is a party's interest in being able to rely on extracontractual representations or promises made by their opposite contracting party (or in other words, their opposite contracting party's honesty and fidelity) even in the absence of a binding legal commitment. As such, I feel that a slightly different term is required in order to avoid confusion. See Fuller \& Perdue, supra note 39 at 54 .

Contractual rights as a species of chose in action clearly constitute a form of property, the value of which can be defined by the present value of the benefits that are expected to flow from these rights. As such, the expectation measure is effectively geared toward vindicating the plaintiff's interest in a future "property." 
business, and as such, does not run afoul of the parties' contract and the limits it imposes on such interests.

Further to the foregoing, additional evidence that the Supreme Court employed an Honest Reliance Measure, distinct from the compensation or expectation measures ordinarily applied in tort and contract, appears in the form of the Supreme Court's regard for Can-Am's notice of termination. As discussed above, the Supreme Court in Bhasin could not vindicate any extant or expected property interest arising from the contract without running afoul of the contract itself. In short, this is the primary reason for which I argue that the Supreme Court must have vindicated an interest separate from Bhasin's economic interests arising in connection with the contract (that is, an interest not spoken to by the contract), and why I assert that the Supreme Court's award (and by extension, DHP itself) vindicates a distinct interest in reliance on extra-contractual commitments or communications. ${ }^{101}$ The Supreme Court's regard for the notice of termination underscores this point and further supports this interpretation, because it follows logically that Bhasin's right to recover for loss suffered as a consequence of relying on a misleading communication would end once the communication was effectively rescinded. By the same token, it is also apparent that if the Supreme Court had instead intended to vindicate an interest arising out of the parties' contract itself, there would be no obvious reason for the court to limit Bhasin's recovery according to whether the deception remained operative.

In sum, it is evident for the reasons given above that the Supreme Court in Bhasin has adopted a measure for relief that exactly accords with the Detrimental Reliance Approach adopted in (and appropriate to) cases of equitable estoppel along the lines developed in Australia. That is, a measure that is intended neither to enforce expectations nor provide total compensation, but instead to prevent detriment that would be suffered in circumstances where misleading statements are made, but only to the extent to which it was reasonable to rely on them, and to the extent that the detriment is truly a consequence of the statements. ${ }^{102}$ Thus, if my position with respect to the interconnection of interests and remedies is accepted and holds true, then it must be accepted that Australian equitable estoppel is an apt characterization of DHP as applied in Bhasin.

Contra Robertson, supra note 35 at 863-64 (does not see the award as consistent with a reliance-type measure, or a finding of reliance by Bhasin).

Waltons Stores, supra note 49 at 402-403 (the purpose of promissory estoppel is not to make good every expectation, because a plaintiff may be expected to appreciate that it is not safe to rely on every representation or promise without some firmer commitment or guarantee); Texas Commerce, supra note 47 ("a mere promise by a party ... will not generally give rise to an estoppel, even if acted on by the promisee, for the promisee may reasonably be expected to appreciate that, to render it binding, it must be incorporated in a binding contract or contractual variation, and that he cannot therefore safely rely upon it as a legally binding promise without first taking the necessary contractual steps" at 107); Verwayen, supra note 2, Deane J:

Ultimately, however, the question whether departure from the assumption would be unconscionable must be resolved not by reference to some preconceived formula framed to serve as a universal yardstick but by reference to all the circumstances of the case, including the reasonableness of the conduct of the other party in acting upon the assumption and the nature and extent of the detriment which he would sustain by acting upon the assumption if departure from the assumed state of affairs were permitted (ibid at 445 [emphasis added]). 


\section{How Waltons' Test Applies to Bhasin}

It is both noteworthy and lamentable that the Supreme Court in Bhasin did not spend much, if any, time on establishing an explicit test or set of criteria for determining whether a breach of DHP has occurred. If we assess the facts of Bhasin against the following six factors laid down by Waltons Stores, however, I suggest that its applicability is evident given the overlap between the factors that preoccupied the Supreme Court and those required by Australian equitable estoppel. If this, and my earlier argument with respect to the remedy in Bhasin is correct, I argue that my overarching argument in this part must be made out, and that it must be clear that Australian equitable estoppel provides an adequate and contextually superior solution to the issues raised in Bhasin than does DHP as described by the Supreme Court. First, however, the facts and the following six factors must be considered:

(1) The plaintiff assumes a particular legal relationship exists with the defendant, from which the defendant is not free to withdraw;

(2) the defendant induced that assumption;

(3) the plaintiff acts (or refrains from acting) in reliance on the assumption;

(4) the defendant knew or intended the plaintiff to do so;

(5) the plaintiff will incur a detriment if the assumption is not fulfilled; and

(6) the defendant fails to act to avoid the detriment to the plaintiff. ${ }^{103}$

The above test can be applied to the facts of Bhasin relatively easily for factors $1,2,3,5$, and 6 as follows:

(1) Bhasin assumed that a merger would not be forced, and that he would be able to retain his agency and continue his business; ${ }^{104}$

(2) Can-Am induced that assumption; ${ }^{105}$

(3) Bhasin refrained from taking any steps to preserve the value of his business, which the Supreme Court concluded he could have done if he had known that his assumption was incorrect; ${ }^{106}$

(5) Bhasin incurred a detriment through the total loss of the value of his agency, when he could have taken steps to reduce that loss; ${ }^{107}$ 
(6) Can-Am did not act to avoid the detriment to Bhasin because it failed to take either of the two options available, which were to either inform Bhasin of the truth, or to renew Bhasin's contract and fulfill his incorrect assumption. ${ }^{108}$

If the foregoing is correct, it would seem that the case for re-characterizing Bhasin as a case of promissory estoppel is all but made. Of course, the one remaining obstacle is the question of knowledge or intent (that is, the fourth factor above), which the Supreme Court purportedly used to distinguish DHP from promissory estoppel in the following terms: "Unlike promissory estoppel and estoppel by representation, the contractual duty of honest performance does not require that the defendant intend that his or her representation be relied on." 109 I say "purportedly" because in my opinion, the Supreme Court's distinction makes no difference given the outcome of the case, as I will explain.

a.

Why Bhasin Does Not Settle the Point on Knowledge or Intention

As noted above, the Supreme Court in Bhasin has explicitly denied that the defendant must have intended that the plaintiff rely on the defendant's representation in order for a claim in DHP to be made out. ${ }^{110}$ I question how definitive this aspect of the Supreme Court's judgment can be, though, if we read between the lines of the decision.

The facts relating to Can-Am's conduct that can be gleaned from a close reading of Bhasin are that Can-Am knew that it did not intend to renew Bhasin's contract, that it intended for Hrynew to obtain the substance of Bhasin's business, and that it knowingly misled Bhasin about the existence of these intentions. ${ }^{11}$ On their face, these findings say little about CanAm's specific "intentions" in making its misleading communications to Bhasin. This is understandable given the Supreme Court's position that these facts are not relevant or in issue as far as DHP is concerned. Considering the following, however, it seems that when probed critically, the validity of this position crumbles.

One of the chief difficulties with interpreting or understanding Bhasin is not so much what it says, as what it does not say. Understanding the situation with respect to the Supreme Court's opinion of Can-Am is most definitely plagued by this problem. It is evident, for instance, that the Supreme Court disapproved of Can-Am's dishonesty, but we are not told why. This unfortunately leaves us to speculate, but I would argue that educated guesses can be made if we consider the "why" behind the "what" of the three aspects of Can-Am's behaviour listed in the preceding paragraph. Starting first with Can-Am's ultimate objective, we know from the judgment that Can-Am wished to (effectively) give Bhasin's business to Hrynew. This might be taken to imply that Can-Am's actions with respect to Bhasin were meant to help achieve this goal. This of course explains Can-Am's intention and ultimate decision to cancel Bhasin's contract. Likewise, assuming that Can-Am's other acts were rationally connected to this objective, I believe that it must explain why Can-Am misled

This question of intention is separate and distinct from the question of whether the defendant has relied on the representation in fact, which will be discussed below.

Bhasin, supra note 1 at paras $97-103,108-109$. 
Bhasin about its plans. This is so because, presumably, if Can-Am misled Bhasin about its plans, it should in all fairness imply that Can-Am was aware that telling the truth may have prejudiced its plans. Put another way, if Can-Am's deception was anything other than capricious or completely unconnected to its larger objective, then it must have acted according to what it knew of Bhasin's mindset and likely response, especially in respect of an unwanted "merger." This simply means that if Can-Am acted rationally, then it intended for Bhasin to rely on its communications to him in the hope that he would carry on business as usual and preserve the value of his business. ${ }^{112}$

\section{b. Why Intention Matters and What to Do About It?}

The analysis above may seem unduly methodical for the purposes of reaching the fairly simple conclusion at the end of the preceding paragraph. However, there are three reasons why it is important to cement the point for the purposes of my argument, and a larger reason as to why it matters for the sake of workability.

The first reason is that the Supreme Court's own position with respect to DHP is that intention on the part of the representor is unnecessary. In my view, this makes it important to stress the apparent presence of intent, and its apparent, if unarticulated, importance to the Supreme Court's own reasoning, because it demonstrates that DHP does not adequately explain the Supreme Court's intervention, and that a better explanation must be found. This better explanation, I submit, is provided by Australian equitable estoppel.

The second reason is that the Supreme Court's opinion on the point of intention can be understood as obiter only, if the presence of intent is made clear on the facts of the case. This distinction is significant in the present case because if the Supreme Court's opinion on this point is not strictly binding, then it leaves the door open for subsequent application of Bhasin to follow a path leading to the effective adoption of Australian approach; lower courts could, if they wished, pursue a course in which DHP is applied according to the principles governing equitable estoppel, even if the explicit adoption of the Australian approach to said estoppel as a distinct development is seen as too large a step at the trial or provincial appellate level. The end reached would be much the same under either route so far as contract is concerned. As such, there is little reason to distinguish between them, other than to note particular modifications that would be necessary if equitable estoppel were to be explicitly adopted as a doctrine of general application outside of contract, which I will do below.

The third reason is to demonstrate that the sense in which "intent" is present in Bhasin, and the sense in which the term is used in Australian decisions, is markedly similar to the way in which intent is already understood with respect to estoppel in Canada currently. That is, the defendant objectively appears aware of what the consequences of their act or representation might be (the Knowledge Approach). ${ }^{113}$ This point is obviously significant

On the basis of the authorities mentioned, I agree with the learned trial Judge that intent and

knowledge on the part of the promisor are necessary ingredients of promissory estoppel. However, the authorities make it clear that intent to create legal relations does not require a direct statement to that effect. Rather, such an intent can be based on an inference drawn from the evidence. 
with respect to the adoption of the Australian approach to equitable estoppel, as it demonstrates that the Australian approach to intent is not foreign to Canada. The point is arguably more important though, with respect to distinguishing between "intent" in equitable estoppel and "intent" as it is understood in the tort of deceit. The latter of these requires, if damages are to be recovered, that the defendant not only intend (or understand) that the plaintiff will act upon the falsehood, but also that the plaintiff's act will result in damage to him or her. ${ }^{114}$ I note that the distinction may seem fine, and in a case such as Bhasin, inconsequential, but it is nonetheless important given that the "intent" required in deceit is a higher threshold, and one that the Supreme Court of Canada might have had foremost in mind when it rejected intention as a requirement for DHP. ${ }^{115}$

The larger problem of workability created by the Supreme Court's insistence that intention is not a requirement of DHP arises because in its absence, there is otherwise no obvious limit to the doctrine's application. ${ }^{116}$ There ought to be some "brake" to stop the expansion of liability short of the point of over-inclusivity. ${ }^{117}$ It is true that a number of limits already appear to be implicit in the Supreme Court's decision, given that five of the six factors from Waltons Stores were at least alluded to in the Supreme Court's decision in Bhasin, but in my opinion, these alone are not enough. The simple reason is that a test or cause of action that embraced only these factors would determine culpability on a purely consequentialist basis or, in other words, create strict liability without any regard for fault. Taken to its logical conclusion, this would quite apparently lead to the spectre of almost indeterminate liability attaching to any act, word, or intimation that could be acted upon by an opposite contracting party, no matter how casual or unconsidered it might have been. At the risk of sounding like an appeal to the floodgates, I would argue that the law should not suffer such an outcome. To avoid it, though, will require either DHP's amendment or its abolition.

\section{The Adoption of Estoppel Subject to ModificAtion}

Before concluding my overall argument, there is one modification that I suggest ought to be made if the equitable estoppel doctrine were to be explicitly adopted from Australian law, rather than by way of modifying DHP. Namely, equitable estoppel should not be adopted as an overarching or "unified doctrine of estoppel," such that it would replace or supplant all other estoppels presently known to Canadian law. ${ }^{118}$ In particular, I argue that there is value

Knowledge by the promisor that the promisee is likely to regard the promise as affecting their legal relations constitutes an appropriate basis from which the inference of the existence of a sufficient intent can be drawn (ibid at 467 [emphasis added]).

114 MacDougall, Misrepresentation, supra note 57, $\$ \$ 5.18-5.19$.

115 Bhasin, supra note 1 at para 88.

116 This is a limit that I think all counsel will agree must be found: see Finkelstein et al, supra note 32 at 372-73 (uncertainty with respect to the scope of DHP extends to issues such as silence or intentional refusal to answer, which can potentially create a very serious dilemma for parties in the real world).

117 Evans v Paradigm Captial Inc, 2016 ONSC 4286, 36 CCEL (4th) 129 (according to Justice Gans, Bhasin now appears to be pleaded almost as a "reflex action" at para 82). See also O'Byrne \& Cohen, supra note 31 at 8-11 (it appears that expansion in favour of voluntary disclosure, rather than just honest answers, is already happening in certain contexts, and that equivocations may also attract sanction in some surprising circumstances).

118 Although the first indications of a unified doctrine of estoppel in the Antipodes had come from the pen of Sir Owen Dixon as early as 1937 in Grundt, supra note 60, some difference of opinions persists as to whether the distinct categories of estoppel remain. It seems more likely than not, though, that distinctions between estoppels now persist in Australian doctrine only so far as remedies are concerned. See Andrew Robertson, "Towards a Unifying Purpose for Estoppel" (1996) 22:1 Monash UL Rev 1 at 29. See also Texas Commerce, supra note 47, Lord Denning MR ("[a]ll these [various estoppels] can 
in retaining a distinct place for estoppel by representation and proprietary estoppel, as these respond to concerns that differ from promissory estoppel in Canadian law. The consequence of doing otherwise and replacing all three doctrines with a single equitable estoppel that is framed in such a way as to principally vindicate interests that are most relevant to only one of these doctrines (that is, promissory estoppel) would be to undermine certainty and efficacy in the law.

The primary basis for my concern is that if all estoppel is subsumed under the one heading, it creates the risk that courts may conflate dissimilar cases that would have been previously dealt with under distinct doctrines with different concerns in mind. An apt example is the distinction between the founding of an estoppel on the basis of a representation of present fact, and one upon the basis of a statement or promise as to the future. With the latter for instance, one can justify allowing a promisor to revert to their prior position with notice, where it would not be inequitable to do so. One might ask though, as I do, when (if ever) would it be right to allow a representor to renege on notice? With a promise or statement as to the future, a promisee may be expected to know or understand that the promisor's word ought to be reduced to contract if it is to be binding, and as such, it may not be inequitable to deny the promisee the full value of the promise or statement where they have not taken such steps to confirm their position. ${ }^{119}$ I would ask, how could the same be true in relation to a statement of existing fact? Clearly, it cannot be. Parties do not generally contract to confirm the state of the world, and one would think that this distinction would be obvious. Nonetheless, if both representations as to past or present and statements as to the future were to be regulated under a single doctrine, it becomes all too likely that misunderstandings may arise, and that mistakes may be made.

\section{CONCLUSION}

In the foregoing, I have demonstrated that an analysis of the facts of Bhasin in terms of a claim in Australian equitable estoppel can and does rationally explain the connection between facts and outcome in that case. Further, the foregoing also demonstrates, from a close reading of the Supreme Court's own recitation of the facts, that the presence of the requisite elements for such an action in estoppel were essential to the Supreme Court's conclusion, and, leaving the Supreme Court's own reasons aside, that DHP may be characterized as equitable estoppel by another name, given the way in which it was actually applied. In other words, it is not a mere coincidence of outward form that renders promissory estoppel an applicable theory of this case. Instead, much to the contrary, it appears that promissory estoppel is an apt bridge from facts to outcome in Bhasin because it more accurately and obviously reflects the logic of the Supreme Court's conclusion than the

now be seen to merge into one general principle shorn of limitations" at 122).

This point has been made with respect to the enforceability of "mere promises" generally, but stands equally true, one might think, in relation to "promises" giving rise to an estoppel. See Texas Commerce, ibid, Goff J:

Such cases are very different from, for example, a mere promise by a party to make a gift or to increase his obligations under an existing contract; such promise will not generally give rise to an estoppel, even if acted on by the promisee, for the promisee may reasonably be expected to appreciate that, to render it binding, it must be incorporated in a binding contract or contractual variation, and that he cannot therefore safely rely upon it as a legally binding promise without first taking the necessary contractual steps (ibid at 107). 
Supreme Court's own reasons for the decision. ${ }^{120}$ Thus, I conclude that the adoption of equitable estoppel as a means to address mischief of the type seen in Bhasin, subject to the modification mentioned above, must be seen as more sensible than the Supreme Court's own approach. 